\title{
Irrigation management of Romaine lettuce in Histosols at two spatial scales: water, energy, leaching and yield impacts
}

\author{
Y. Périard ${ }^{1}$, J. Caron ${ }^{1}$, S. Jutras ${ }^{2}$, J. A. Lafond ${ }^{1} \&$ A. Houlliot ${ }^{3}$ \\ ${ }^{1}$ Département des sols et de génie agroalimentaire, \\ Université Laval, Canada \\ ${ }^{2}$ Département des sciences du bois et de la forêt, \\ Université Laval, Canada \\ ${ }^{3}$ Agrocampus ouest, Institut national de l'Horticulture \\ et du Paysage, France
}

\begin{abstract}
Lettuce is an important crop in Canada, mainly grown in South West Quebec muck soils. Lettuce is sensitive to water stress during periods of high crop water requirements, which result in important yields decrease mainly due to tip burn. This physiological disorder can be controlled by adequate irrigation, which is affected by spatial distribution patterns of water needs at different field scales. Such patterns result from spatial variability of soil properties and water drainage, and from evapotranspirative processes affecting local crop water needs at a given time. This study aimed at evaluating irrigation management performances (water and energy consumption, leaching and yield) for Romaine lettuce in a Histosol at two spatial scales, local and global ( 0.5 and $7 \mathrm{ha})$. Three field experiments were performed during summers 2010 and 2011 at two sites of 7 ha presenting a high spatial variability in available water (AW). The set up was divided into three zones equipped with wireless tensiometers. The critical irrigation threshold for initiating irrigation was $-30 \mathrm{kPa}$ for a low $(<4 \mathrm{~mm})$ potential evapotranspirative (ET) demand and $-15 \mathrm{kPa}$ for a higher ET $(>4 \mathrm{~mm})$ [1]. Results indicated that local irrigation management has resulted in marketable yield increase of 16.5 to $18.2 \%$ depending on years, but resulted in 21.2 to $23.6 \%$ more water (and consequently energy) use with respect to global management. Higher frequency
\end{abstract}


and quantity of applied irrigation water has resulted in higher tracer leaching in the second year in the local irrigation management approach.

Keywords: precision irrigation, available water, Romaine lettuce.

\section{Introduction}

In Canada, in 2010, about 528570 ha of irrigated lands are cropped annually and require 838 millions of cubic meters of water among which $9.3 \%$ is used for vegetable production [2]. Quebec owns 3\% of the total irrigated surfaces in Canada with a consumption of about $1.5 \%$ of the total volume of water used in Quebec. In Quebec, lettuce is a vegetable crop of importance with a total of 59 312 tons produced annually [3]. Representing $84.2 \%$ of the total Canadian production, the crop is grown on 2800 ha mainly in Histosols, which is $75 \%$ of the production surfaces. Lettuce presents an important risk of water stress during periods of high ET requirements $(>4 \mathrm{~mm})$ [1] throughout the growing season, mainly due to inadequate rainfall distribution and variability in soil water availability at a given time.

Several factors influence that variability. First, the uniformity of applied water may vary from 40 to $95 \%$ depending on the irrigation system used [4], then most likely not corresponding to local plant needs within the field [5] and provoking variable infiltration patterns [6]. Second, once applied to the soil, the main parameters influencing water supply to the crop are the soil physical properties like the water desorption curve, the hydraulic conductivity, soil available water, all of which are spatially dependent. Spatial variability of soil physical properties influence water uptake by the crop [7] and is a dominant factor explaining variability in yields [5]. In Iowa, a variation of $69 \%$ in soybean yields was associated with an important heterogeneity of soil water retention [7]. Third, the availability of the water will be influenced by the crop production itself: row distribution, crop architecture, plant size and growth stage, root distribution, tillage among others [8]. The combination of these factors may result in a water uptake below full plant needs, and then a higher tip burn for the lettuce crop [1].

When initiating irrigation, two questions must be solved: when to and how much apply water. While ET models may adequately estimate the amount of water to apply to compensate for the evapotranspirative losses, which may be sometimes a questionable assumption, there is still a need to estimate local needs in soils of high variability [9]. Indeed, ET models provide field or regional estimates of potential evapotranspiration, hence independent of soil variability patterns. Moreover, they can't provide estimation of the existing soil water status as it evolves rapidly, subject to all previously highlighted processes. Finally, such models do not use soil based measurements and may then drift with time, resulting in a mismatch between plant needs and real uptake.

Thus, establishing a sequence of irrigation priority should ideally take into account the resulting interaction of these factors on water availability and should therefore be backed by real-time information of water status at different soil locations at a given time. Such system can rely on water content or water 
potential probes measurements. As already mentioned, even with a uniform water application, plant uptake and topography, soil water potential may present an important variability due to spatial structure of unsaturated and saturated hydraulic conductivity, of pores and particle size distribution $[10,11]$ and of soil structure $[4,11,12]$. In organic soils, a large variability in organic horizon depths and available water of organic horizons has been reported [13].

Managing this variability may be impossible if the pattern is due to pure random in time and space. However, a large temporal stability in spatial patterns of water content and water potential has been reported, even if it varies according to crop growth stage [8], because rate of plant uptake depends on crop ET [14, 15]. Then, the pattern due to physical properties must be present at scales that are manageable and constant in time (temporally stable), which means a spatial structure over a plot large enough so that local water applications are feasible and can compensate for these fluctuations. Therefore, the temporal and spatial structure may strongly affect the expected performances of local and global management of irrigation and create differences between expected and observed performances.

Since the 90s, researches have been conducted evaluating the effect of irrigation management subject to spatial variability and comparing local versus global (whole field) approaches to evaluate irrigation needs and apply water at different field scales. Most of the studies have been conducted with central pivot system with variable application rate of irrigation water [16-18]. When comparing approaches, some of the studies has evaluated yield [19-22], water consumption $[7,9,19,21,23-27]$, water use efficiency $[12,25]$, drainage $[7$, $12]$, energy consumption $[12,27]$ and gross additional margin [7, 20, 25]. The wide majority of these studies pointed out towards yield increases with reduced water consumption, thus resulting in increased water use efficiency. However, most of the studies were performed with simulations and little of them were supported by field experiments. Field validation of potential performances is required as simulation based and variable soil properties cannot take into account possible interacting factors linked to other crop limiting conditions (irrigation uniformity, fertilization, pest and weed control) as well as soil conditions (drainage, differential plant water uptake, among others). The objective of this study was therefore to evaluate field scale performances (water and energy use, leaching and yield) of two scales (local 0.5 ha and global $7 \mathrm{ha}$ ) of irrigation management for Romaine lettuce in an organic soil.

\section{Material and methods}

\subsection{Experimental design}

The experiment was set up during the summer of 2010 and 2011 in Romaine lettuce fields in Quebec (Canada) $\left(45.15^{\circ} \mathrm{N}, 73519^{\circ} \mathrm{W}\right)$. The experimental site was chosen based on the observation of a strong variability in available water and in thickness of the organic soil layer (fig. 1). The depth of organic soils was closely correlated with available water for plants as roots develop at a fast rate 
( 2.0 to $2.5 \mathrm{~cm} \mathrm{day}^{-1}$ ) in organic horizons but is rather limited by heavy clay of the lower horizon or the presence of a severely compacted humic Oh horizon [28]. The heterogeneity of soil properties within the experimental site justified the use of an experimental design similar to a split-plot. As main plot, soil water availability was a fixed factor and at the level of the subplot, the fixed effect was irrigation management randomly assigned to experimental units of a same block. The thickness of organic soil and the AW is shown in figure 1. The map was produced by ordinary kriging after a geostatistical analysis in $\mathrm{GS}^{+}$software (Gamma software 2007, Plainwell, Michigan, USA), as explained in detail by Lafond et al. [13].
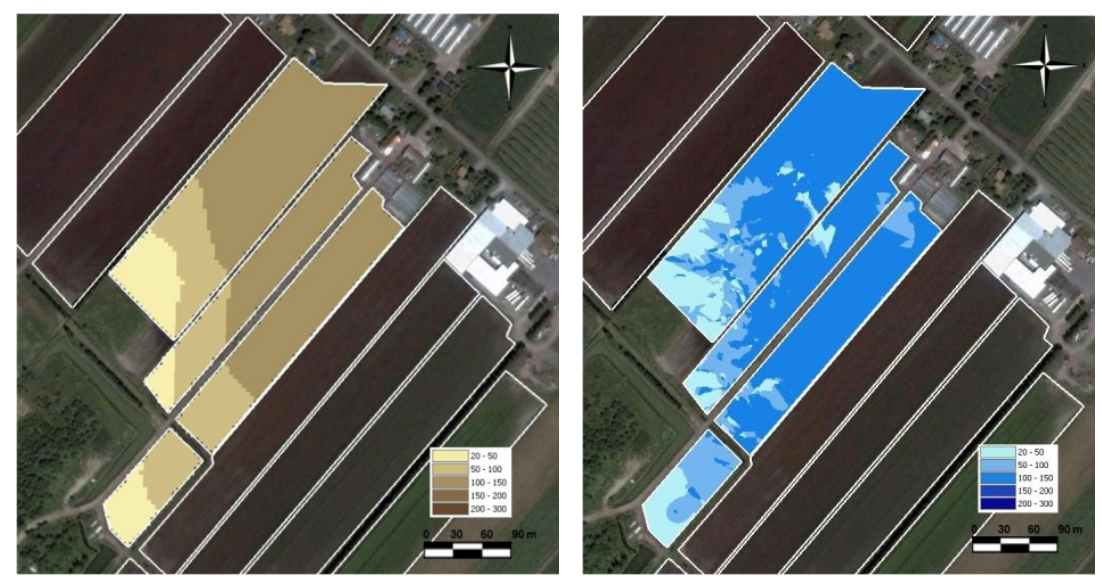

Figure 1: Spatial variability of organic soil depth $(\mathrm{cm})$ (left) and soil available water $(\mathrm{AW})(\mathrm{mm})$ (right).

The experimental setup for the years 2010 and 2011 is shown on figure 2 . The experiment was repeated twice during the summer of 2010 to cover the entire growing season and increase the number of replicates. One experiment was also performed in 2011 .
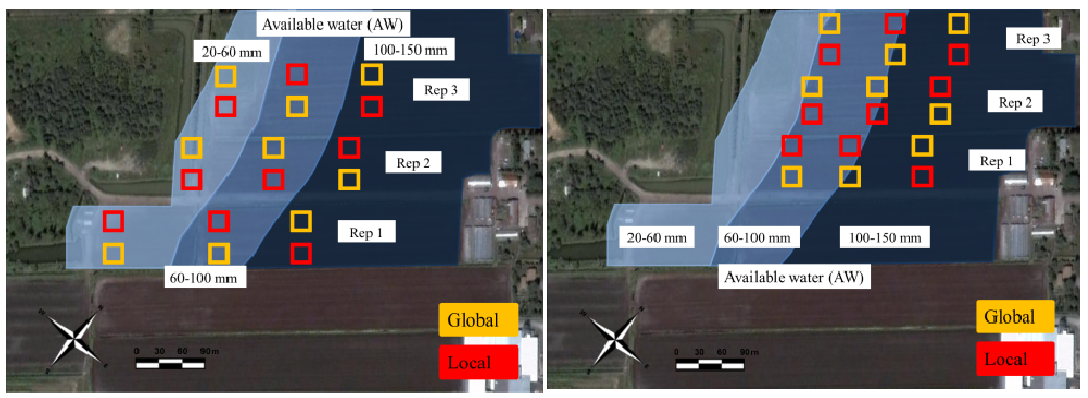

Figure 2: $\quad$ Experimental site in 2010 (left) in 2011 (right) with available water (AW) zones specified in white rectangles. 
The experiment was replicated three times at different locations (fig. 2). Following the pattern of spatial variability of organic soil depth and available water, the experimental site was subdivided into three distinct zones. In 2010, the first zone had an organic soil thickness of 20-50 cm (available water 20-60 mm), of 50-100 cm (AW 60-100 mm) for the second zone, and of 100-140 cm (AW $100-150 \mathrm{~mm}$ ) for the third. In 2011, the experimental design was modified to test the performance of local management in a field with lower heterogeneity of AW then in 2010. The first zone had an organic soil thickness of 60-80 cm (AW 60$80 \mathrm{~mm}$ ), the second area had $80-110 \mathrm{~cm}$ (AW $80-110 \mathrm{~mm}$ ) and the third zone had 110-140 cm (AW 110-150 mm). Available water was defined as:

$$
A W_{(x, y)}=\sum_{i=1}^{n}\left(\theta_{c}\left(z_{i}\right)-\theta_{w}\left(z_{i}\right)\right) \Delta z_{i}
$$

where $\mathrm{n}$ is the number of different organic horizons, itself dependent on spatial coordinates $(\mathrm{x}, \mathrm{y}), \theta_{\mathrm{c}}$ is the water content at field capacity $\left[\mathrm{mm}^{3} \mathrm{~mm}^{-3}\right]$ and $\theta_{\mathrm{w}}$ is the water content $\left[\mathrm{mm}^{3} \mathrm{~mm}^{-3}\right]$ at plant stress onset $(-30 \mathrm{kPa}$ of matric potential for lettuce; personal observations) at depth $\mathrm{z}_{\mathrm{i}}[\mathrm{mm}]$.

Experimental units measured $27 \mathrm{~m}$ by $27 \mathrm{~m}$. Each experimental unit had three nozzles VYR 35 (VYR, Burgos, Spain) with a nozzle of $5.55 \mathrm{~mm}$. All nozzles were installed with water meters (LR-F-7083/4", Lecompte Counters Ltd., SaintHyacinthe, Quebec, Canada). Subsequently, sprinklers and water meters were screwed onto aluminium tubing of $7.62 \mathrm{~cm}$ diameter (Wade Rain, Tualatin, Oregon, USA) by $9.14 \mathrm{~m}$ long. The pump model used was a NSPHE-500 (Monarch Industries. Winnipeg, Manitoba, Canada). At the outlet of the pump, a valve was installed to maintain a pressure of $5.07 \mathrm{kPa}(35 \mathrm{psi})$ at the nozzles.

\subsection{Management of irrigation by tensiometry}

In each experimental unit, three wireless tensiometers (Tx-80-WL, Hortau Inc., St. Romuald, Quebec, Canada) were installed at three different depths $(15 \mathrm{~cm}, 30$ $\mathrm{cm}$ and $45 \mathrm{~cm}$ ), with wireless relays (Hortau Inc., Saint-Romuald, Quebec, Canada) and transmission modules to allow real time collection of field data. Three tensiometers were positioned between two lettuces after planting on the third bed west of the irrigation line and between two nozzles to reduce the possible variability due to irrigation pattern. Irrigation was triggered once threshold of soil matric potential were reached. The calculation of the matric potential for decision at a specific location was performed using the average matric potential reached in the root water uptake zone, using the three depths. For the first fifteen days of the growing cycle, only the matric potential at $15 \mathrm{~cm}$ depth was considered. Then, for the sixteenth to thirtieth day, the diagnosis of matric potential took into account the average of matric potential at 15 and $30 \mathrm{~cm}$ in the profile. Finally, before harvest, between days thirty-first and forty-fifth, the diagnosis of matric potential was determined by averaging the whole three tensiometers data $(15 \mathrm{~cm}, 30 \mathrm{~cm}$ and $45 \mathrm{~cm})$.

Results obtained earlier on Romaine lettuce in Histosols indicated an approximation threshold at $-30 \mathrm{kPa}[29,30]$, consistent with estimates in a mineral soil [31]. Therefore, the threshold for critical matric potential of the 
irrigation setpoint was set at $-30 \mathrm{kPa}$ for the two years. However, for the year 2011, when evapotranspirative demand was greater than $4 \mathrm{~mm}$ day $^{-1}$, the threshold was increased to $-15 \mathrm{kPa}$, as earlier simulations indicated that at high ET, the soil supply would not be enough [1]. Hence, whenever the average matric potential reached the threshold, irrigation was initiated. In the local approach, each experimental unit was managed independently and the diagnosis of matric potential was individually determined by the matric potential from all sensors located within this specific experimental unit (EU). In the global management, the diagnosis of matric potential was made using the average of all experimental units over all three replicates $(9 \mathrm{EU})$, and hence the average of all experimental units should have reached the threshold before irrigation was performed at the same time for all 9 plots.

\subsection{Yields}

At the end of each experiment, 20 lettuces were harvested using a systematic sampling in each of the experimental units. Each lettuce was evaluated on the following variables: total mass, marketable mass, length of lettuce (the longest leaf), number of leaves longer than $1.5 \mathrm{~cm}$, length of the heart, disease, and physiological disorders (tip burn). Overall, marketable biomass and marketable yield were also evaluated. Only the proportion of lettuce affected by tip burn, marketable biomass and marketable yields will be discussed, for length constraints. Marketable yields were based on a threshold decision to harvest commonly used by producers of lettuce. When a field had more than $15 \%$ of lettuce affected by tip burn, it was not harvested and ploughed down. Hence, all plots with more than $15 \%$ of lettuce affected by tip burn were considered as having a marketable yield of zero.

\subsection{Energy consumption}

The energy consumption was assessed by measuring the operating current (in amperes) of the electric pump during irrigations. Knowing the operating time, the intensity (18 amps) and voltage $(230 \mathrm{~V})$ required, energy consumption $(\mathrm{kJ})$ was determined using the following formula applies for $\mathrm{AC}$ with a power factor of $100 \%$ :

$$
C_{e}=I \times U \times t
$$

where $\mathrm{C}_{\mathrm{e}}$ is the energy consumption [J], $\mathrm{I}$ is the intensity [A], $\mathrm{U}$ is the voltage $[\mathrm{V}]$ and $\mathrm{t}$ is time $[\mathrm{s}]$

\subsection{Water consumption}

Water consumption was measured using rain gauges installed within each experimental unit. Records of water levels were made at the end of each irrigation and rainfall was measured by a rain gauge with a weather station close to the experimental site. Water consumption from all sources was calculated as follows: 


$$
C_{w}=I r+R+\Delta S
$$

where $C_{w}$ is the consumption of water [mm], $I r$ is irrigation [mm], $R$ is the rainfall [mm] and $\Delta S$ is change in water storage [mm], defined as:

$$
\Delta S=\sum_{i=1}^{n}\left(\theta_{t+1}\left(z_{i}\right)-\theta_{t}\left(z_{i}\right)\right) \Delta z_{i}
$$

$\theta_{\mathrm{t}+1}$ is the water content at time $\mathrm{t}+1$ and at depth i $\left[\mathrm{mm}^{3} \mathrm{~mm}^{-3}\right], \Delta z_{i}[\mathrm{~mm}]$ is the soil thickness in the profile. The water storage was calculated from the values of matric potential taken at the beginning and the end of the experiment by tensiometers located at each of the three depths. Then, the values of matric potential were converted to water content using van Genuchten model [32]:

$$
\begin{gathered}
\theta(h)=\theta_{r}+\frac{\theta_{s}-\theta_{r}}{\left[1+|\alpha h|^{n}\right]^{m}} \\
m=1-\frac{1}{n}, \mathrm{n}>1
\end{gathered}
$$

$\theta_{\mathrm{r}}$ and $\theta_{\mathrm{s}}$ denote the residual and saturated water content $\left[\mathrm{mm}^{3} \mathrm{~mm}^{-3}\right], \alpha$ $\left[\mathrm{mm}^{-1}\right]$ and $n$ [unitless] are parameters that define the shape of water retention function according to $\mathrm{h}$, which is the pressure head $[\mathrm{cm}]$ converted from $\mathrm{kPa}$ readings.

\subsection{Water use efficiency}

The water use efficiency (WUE) was calculated using the following equation:

$$
W U E=\frac{Y_{m}}{C_{w}}
$$

where $Y_{m}$ is marketable lettuce yield $\left[t h a^{-1}\right]$.

\subsection{Simulation of scale dependent irrigation management on yield and water use}

The simulation was realized with the soil water availability map generated with the same procedure used in the experimental design section, and the same site as for field experiments was used to compare observed and simulated performances. The $\mathrm{GS}^{+}$software (Gamma software 2007, Plainwell, Michigan, USA) was used to generate maps with different discretization of $\mathrm{AW}_{(\mathrm{x}, \mathrm{y})}$. This step has allowed simulating 6 scenarios with different size of site-specific management unit (SSMU) that 1, 2, 3, 5, 10, 15 SSMUs. The rainfall was not considered in the calculation procedure, the only source of water being irrigation. In the simulation, a constant ET demand of $3 \mathrm{~mm} \mathrm{~d} \mathrm{~d}^{-1}$ during 45 days corresponding to one crop growing cycle was assumed. Therefore $135 \mathrm{~mm}$ of water was needed to meet crop ET. All maps were compared to the map with the most important discretization (15 SSMUs). Hence, the simulation calculated the yield response to the total applied irrigation water within each zone and then compared it to the map with 15 SSMUs. Yield (Y) was assumed to be linearly 
dependent on deficit or excess of water predicted in a given zone based on a similar study [29] and calculated with eqn (7).

$$
Y(S S M U)=\frac{\sum_{i=1}^{n}\left(1-\left(\frac{\left|135-A W\left(S_{i}\right)-A W_{15}\left(S_{i}\right)\right|}{135}\right)\right) 47.44 \times \Delta S_{i}}{S_{T}}
$$

where $A W_{15}\left(S_{i}\right)$ is available water in SSMU $i$ of map which have 15 SSMUs $[\mathrm{mm}], 47.44$ is the maximum yield $\left[t h a^{-1}\right], \Delta S_{i}$ is the surface of the SSMU $i[h a], \mathrm{n}$ is the number of sub units in the SSMU considered (1 to 15), and $S_{T}$ is the total area of the field [ha ]. The water used (W) was defined as:

$$
W(S S M U)=\sum_{i=1}^{n}\left(135-A W\left(S_{i}\right)\right) \Delta S_{i}
$$

\subsection{Evaluation of leaching}

Evaluation of leaching was performed using an inert tracer. Indeed, several studies on solute transport in organic soil use bromide as a tracer [33, 34]. In this experiment, potassium bromide $(\mathrm{KBr})$ was applied at the ground surface in a plot $180 \mathrm{~cm}$ by $50 \mathrm{~cm}$ which contained 12 lettuce plants. The quantity of KBr used, was $20 \mathrm{~g}$, or $13.43 \mathrm{~g}$ of bromide, dissolved in $1800 \mathrm{ml}$ of bi-distilled water. This bromide solution was uniformly applied by several passages at right angle using a conventional hand sprayer. Soil sampling was performed prior to $\mathrm{KBr}$ application to characterize bromide initial concentrations through the soil profile and then, performed at harvest time, at seven different depths, 0-15 cm, 15$30 \mathrm{~cm}, 30-45 \mathrm{~cm}, 45-60 \mathrm{~cm}, 60-75 \mathrm{~cm}, 75-90 \mathrm{~cm}$ and $90-105 \mathrm{~cm}$. At harvest, three lettuce plants with their roots were harvested within each plot. Subsequently, the determination of the bromide concentration in solution was performed on soil and plants. Sample bromide concentration was determined from a saturated soil extract [35]. The soil used was not dried before extraction. A subsample was dried at $70^{\circ} \mathrm{C}$ for 48 hours to determine the mass of water in $\mathrm{g}$ $\mathrm{g}^{-1}$, before saturation of the sample. The water added to saturation was weighed in order to calculate the exact amount of bromide in $\mathrm{mg} \mathrm{kg}^{-1}$ of dry soil. Vacuum filtration was performed with a filter paper Whatman \#42 (GE Healthcare UK Limited, Buckinghamshire, UK). Subsequently, the filtrate was diluted 5 times prior to determination by high performance liquid chromatography (HPLC) (Waters, Milford, MA). Plant tissues were dried at $70^{\circ} \mathrm{C}$ for 72 hours and ground to pass a $0.55 \mathrm{~mm}$ sieve. Next, a $0.1 \mathrm{~g}$ sample was suspended in $10 \mathrm{ml}$ of bidistilled water and placed in a heat bath at $85^{\circ} \mathrm{C}$ for two hours and stirred every half hour. The extract was filtered through a paper Whatman \#42 and diluted 5 times for HPLC bromide determination. Subsequently, a partial mass balance was calculated using each soil horizon and respective bulk density over the whole area where the application took place. Bromide leaching was calculated as:

$$
B r_{l}=S \sum_{i=1}^{n} \Delta Z_{i} C_{i} \rho_{i}
$$


$S$ is the surface of the experimental unit $\left[\mathrm{cm}^{2}\right], \Delta Z_{i}$ is the horizon $i$ thickness $[\mathrm{cm}], C_{i}$ is the bromide concentration of $i\left[\mathrm{~g} \mathrm{~g}^{-1}\right], p_{i}$ is the bulk density $\left[\mathrm{g} \mathrm{cm}^{-3}\right]$ of the $i$ horizon, and $n$ the number of horizons. Moreover, it was possible to estimate the portion of bromide absorbed by lettuce compared to what had been applied to obtain bromide use efficiency coefficient as:

$$
\operatorname{BrUE}=\frac{\sum_{i=1}^{n} C_{i} W_{i}}{M_{a p}}
$$

$C_{i}$ is the bromide concentration in dry vegetable tissue of lettuce $i\left[g g^{-1}\right], W_{i}$ is the dry weight of the lettuce $i[g], M_{a p}$ is bromide applied on the ground surface $[g]$.

\subsection{Statistical analyses}

All statistical analyses used to evaluate the scale dependant irrigation management effects (global vs. local) were performed using the mixed procedure of the R software [36]. The lme function with the nlme library [37] for variables following a normal distribution and lmer function of the general mixed procedure of library lme4 [38] for the binary variable of presence of tip burn were used. Furthermore, the modelling of the variance-covariance matrix of the error term was performed to meet the different assumptions required for analysis of variance. The model of exchangeable correlation structure allowed for some variables to impose a fixed correlation for observations within the same
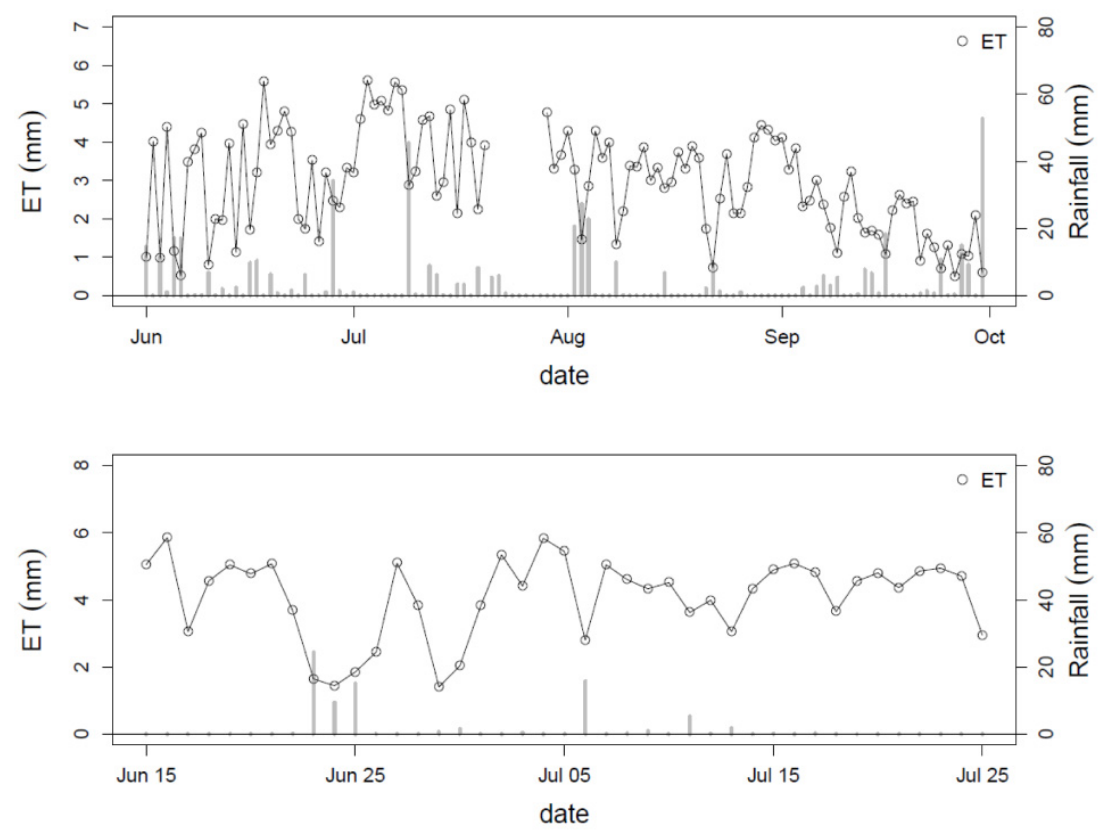

Figure 3: Daily rainfall and ET for 2010 (top) and 2011 (down). 
treatment of a same replicate. When heteroscedasticity was observed, the variance was modelled for the different treatments. The significance level chosen was $5 \%$. The statistical model has tested the fixed effects of irrigation management (global and local) on the performance variables. Statistical analysis in 2010 grouped the two experiments since they were conducted under similar weather conditions (fig. 3) and same spatial variability of AW. In 2011, only one experiment was carried out and statistical analyses were processed independently because the site had a lower spatial variability of AW. In addition, weather conditions in 2011 were very different from those of summer 2010, as well as planting date. Finally, the irrigation trigger was modified when the predicted ET for the following days was greater than $4 \mathrm{~mm} \mathrm{~d}^{-1}$.

\section{Results and discussion}

The first remarkable effect of local management was on tip burn and marketable biomass (fig. 4). Local management has allowed a very significant reduction in the proportion of lettuce affected by tip burn with respect to global management for the first year, for both experiments. Indeed, a reduction of $37 \%$ of lettuce affected by tip burn was obtained on that year, while in 2011, a consistent trend $(\mathrm{P}=0.062)$ but less pronounced ( $5 \%$ reduction in tip burn) was also obtained. This reduction was mainly due to the fact that a matrix potential threshold of -15 $\mathrm{kPa}$ for all the plot sizes during high ET periods has most likely allowed a significant reduction in the proportion of tip burn affected lettuces in 2011 relative to 2010 in the global management treatment. The application of this higher threshold may have contributed to significantly reduce differences in matric potential between different zones, particularly in period of high tip burn risk (high ET). Moreover, a less important difference between dates of seeding from one zone to the other in 2011 may have reduced differences in matric potentials between zones under local management, as differences in plant growth stage would increase spatial distribution variability in matric potential between
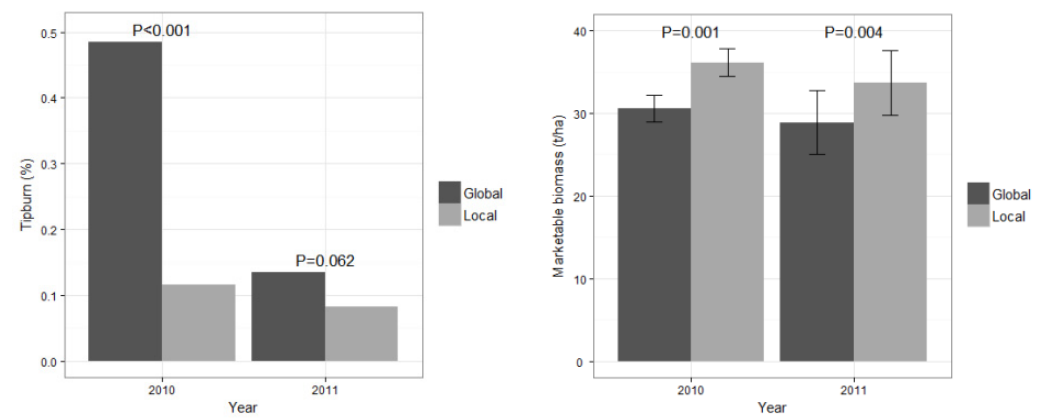

Figure 4: Proportion of lettuce affected by tip burn (left) and marketable biomass (right) for year 2010 and 2011. Year 2010 represents the mean of two replicated experiments while 2011 represents the output of a single replicated experiment. 
different locations in the large plot size at a given time. Finally, the site in 2011 was more uniform, hence likely resulting in less pronounced differences between plots.

A significant reduction of tip burn affected plants (less than $15 \%$ of the plant affected) is a very important target for growers as above this threshold, the field is usually not harvested and subsequently ploughed down and lost. Therefore, the used water is simply pumped and returned to the soil and nutrient stored in residue likely to be mineralized and leached later in the fall. So, if local management of irrigation allows better control of this problem at the field scale, many lettuce crops may be saved and both water and fertilizer be used more efficiently.

With respect to marketable biomass in 2010, a higher biomass in local management was obtained, that is 35.1 tons per ha versus 30.6 tons per ha in the global management approach, which represents a gain of $18.2 \%$. In 2011 , local management also resulted in a significantly higher biomass with 35.7 tons relative to 28.9 tons in global management, which represents a net gain of $16.7 \%$. These results are in between those obtained by others. They are clearly better than those obtained by King et al. [25] in 2006, (4 to 6\% in potato yield increase), by Nijbroek et al. [7] with a simulated $1 \%$ yield increase, by Lu et al. [20] with 1 to $2.5 \%$ increase with the variable rate irrigation system relative to uniform irrigation and by DeJonge et al. [21] with no yield increase for corn. They support those of El Nahry et al. [22] obtaining a $66 \%$ yield increase in local management with four subunits with different soil properties.

The pronounced effect on tip burn had a dominant influence on marketable yield (fig 4). Marketable yield increased by 23 tons per ha in local management relative to global management in 2010 . A poor timing between water application and crop water uptake for different planting dates may have contributed to these high losses in the global management. In 2011, no significant gain in marketable yield was obtained in local versus global management. This may be due to the drastic drop in the proportion of tip burn affected plants in the global management relative to the local one, this drop being most likely linked to the raised threshold added in the irrigation treatments during high evapotranspirative demand, and more uniformity in the plots.

The observed associated energy consumption was higher for local management relative to global management. Indeed, in 2010, energy consumption was $57222 \mathrm{~kJ}$ for local management and $0 \mathrm{~kJ}$ for global management as rainfall was enough to maintain an average water potential higher than $-30 \mathrm{kPa}$. In 2011, energy consumption was $141208 \mathrm{~kJ}$ for local management relative to $116498 \mathrm{~kJ}$ for global management, thus resulting in an increase of $24710 \mathrm{~kJ}$. This increase in consumption contrasts with that of Hedley et al. [12] who observed a reduction (9 to $19 \%$ with local irrigation management) and that of Jobbágy et al. [27] who simulated energy savings of $30.8 \%$ with respect to global irrigation management. This energy increase in the local management may be attributed to more frequent irrigations, linked to a larger biomass to irrigate (figs 4 and 5). 

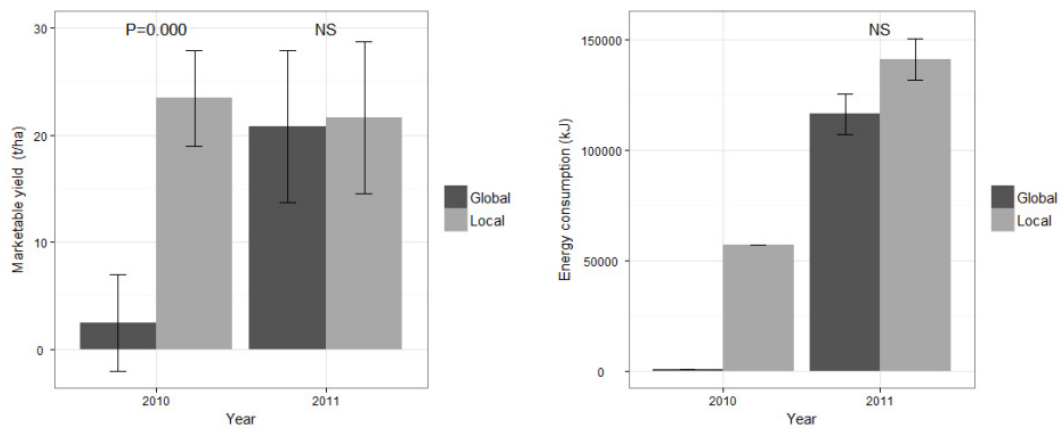

Figure 5: Lettuce marketable yield (left) and energy consumption (right) for year 2010 and 2011 .

Indeed, water consumption, from all origins (rainfall, irrigation, change in storage) and water use efficiency were significantly higher for local management for year 2010 and 2011 (fig 6). In 2010, the consumption was $180 \mathrm{~mm}$ in local management compared to $145 \mathrm{~mm}$ in global management, for an increase of 35 $\mathrm{mm}$ (significant at a 0.05 level). For 2011, an additional $20 \mathrm{~mm}$ of water was applied in local relative to global management (not significant though). Again, these results are in contrast with those of King et al. [25] and Nijbroek et al. [7] who haven't observed differences between both approaches. Results for both years also disagree with those of Hedley and Yule [39] who had reductions of $21.8 \%$ to $26.3 \%$ for applied water and Hedley et al. [12] with water savings of 9 to $19 \%$. Reduction of applied water in local management relative to a global approach were obtained (20\%) by Oliveira et al. [24] and by El Nahry et al. [22] who have also reduce water consumption by $23 \%$ with a central pivot irrigation system in a 62.2 ha field. Additional authors [23, 26], and Jobbágy et al. [27] obtained savings with local management.
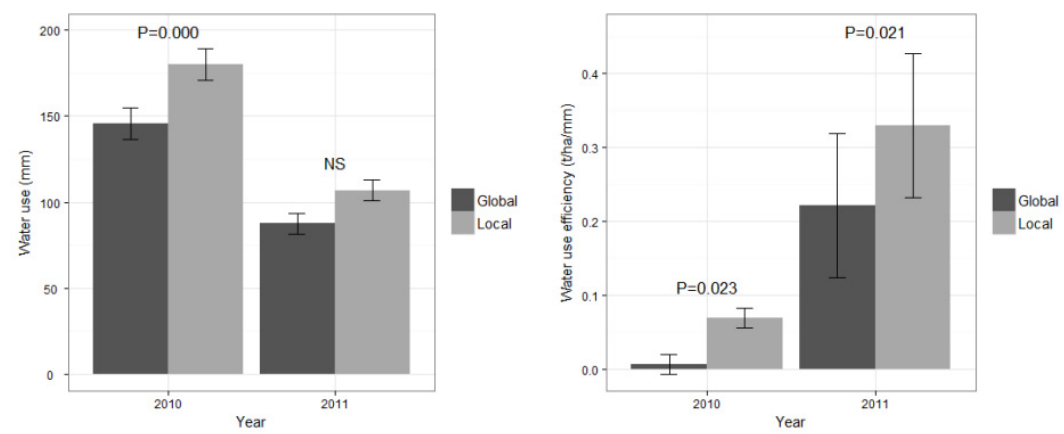

Figure 6: Water use (left) and water use efficiency (right) for years 2010 and 2011. 
Some authors predicted an opposite trend thought. Indeed, Feinerman and Voet [19] predicted increase in water consumption of $41 \%$ when irrigation was managed locally within 16 different zones with respect to their uniform irrigation management across the whole field. Apparent discrepancies may be due to the use of simulated and experimental data. However, further investigations indicated that performances in water use are most likely linked to a scale process investigated in this study at least (fig. 6 and 7). Indeed, simulations indicated that going from an entire 8.5 ha field and subdividing it in subplots would allow a decrease in water used if the field was divided in 4 or 5 subplots and to more water being used if 15 subplots were irrigated. This is in part due to the increased in biomass observed when going from the entire field to local subunits ( $9 \mathrm{EU}$ ) (fig. 4). Because results expected from simulations and observed data were of similar magnitude and linked to increased biomass production, it then becomes more likely the dominant factor explaining the increased water use. This apparent additional use of resources is not wasted though as a higher marketable yield is obtained. Indeed, when the water use efficiency is computed, an inverse portrait is observed. Hence, with that latter index, local management has resulted in increased water use efficiency of $0.07 \mathrm{t} / \mathrm{ha} / \mathrm{mm}$ with respect to $0.007 \mathrm{t} / \mathrm{ha} / \mathrm{mm}$ for global management in 2010 (fig. 6). Moreover, in 2011, local management has resulted in increased water use efficiency with $0.33 \mathrm{t} / \mathrm{ha} / \mathrm{mm}$ compared to $0.22 \mathrm{t} / \mathrm{ha} / \mathrm{mm}$ obtained with global management. In the former year, this was caused by the pronounced reduction in marketable yield resulting from a high proportion of tip burn affected lettuce. As mentioned earlier, the higher irrigation frequency in the latter year favoured higher water contents and lower soil water potentials, thus resulting in a better control of tip burn under local management. As shown in figure 6, the overall water use efficiency for both approaches was lower in 2010 than in 2011. This is mainly attributed to higher rainfall during

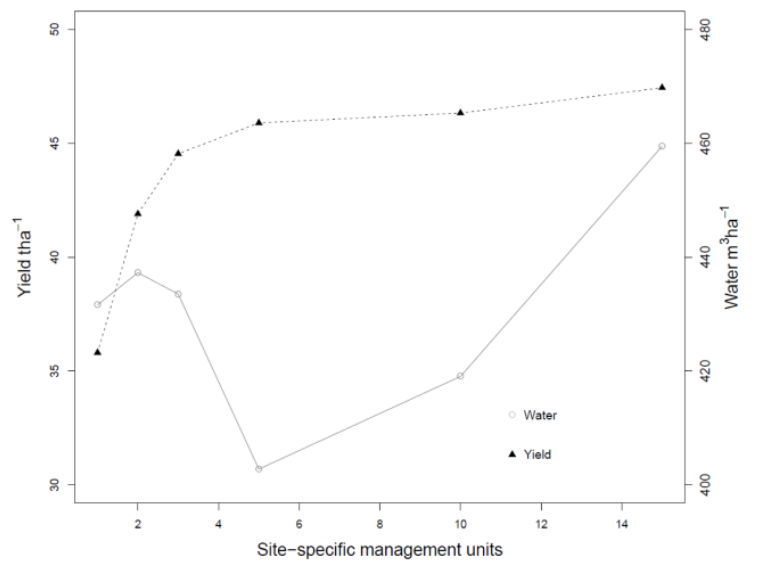

Figure 7: Simulated water use and yield in function of the size of site-specific management units. 
growth in $2010(145 \mathrm{~mm})$ and very little rainfall in $2011(20 \mathrm{~mm})$, (fig. 3). These results disagree with those of King et al. [25] who obtained no increase in water use efficiency despite a trend for higher efficiency under local management. These increases in water use efficiency were lower than those obtained by Hedley et al. [12] who had a 10 to $21 \%$ increases.

Consistent with data on water applications, local management resulted in more leaching (fig. 8) because of more applied water in 2011. Indeed, significantly more bromide was leached from the profile under local management (fig. 8) and more bromide was recovered in the global management approach (fig. 9). This may be explained by a higher proportion of bromide found in the global management at the top surface significant for both years (fig. 10), thus resulting in a reduced risk of leaching for this tracer. This is caused by more frequent and more abundant irrigations in local versus global management, which favoured maintaining higher unsaturated soil hydraulic conductivities, thus favouring a faster bromide transport towards lower horizons. Maintaining a soil matric potential higher then $-15 \mathrm{kPa}$ under high crop ET requirements may have contributed to this phenomenon.
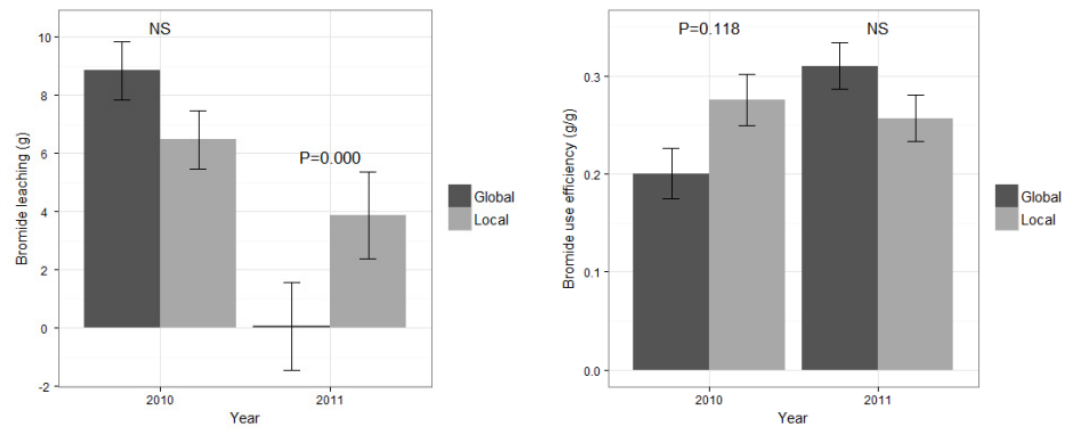

Figure 8: Leaching (left) and bromide use efficiency (right).

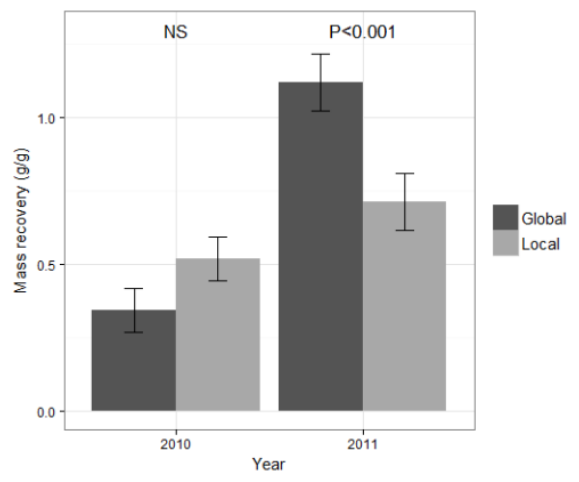

Figure 9: Bromide mass recovery. 

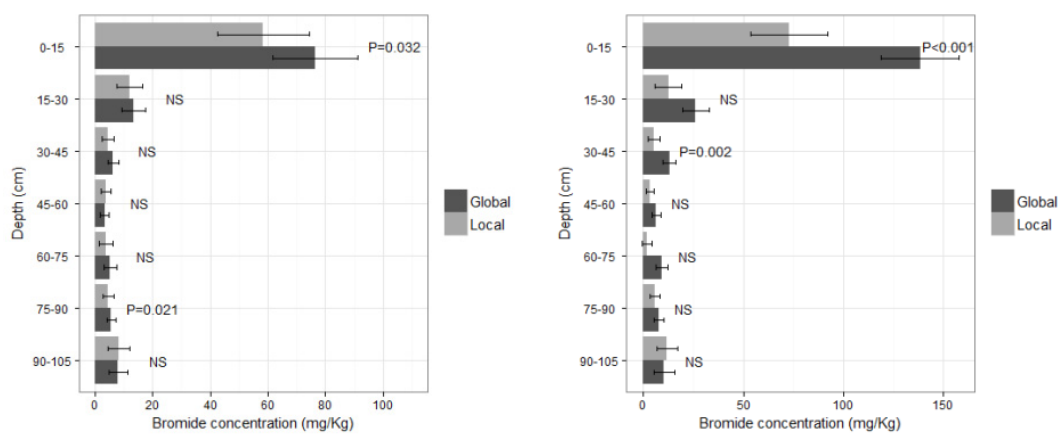

Figure 10: Distribution profile of soil bromide concentration in 2010 (left) and 2011 (right).

So, our results differed from those of Hedley et al. [12] who obtained a leaching reduction of 25 to $45 \%$. However, Nijbroek et al. [7] obtained, by simulation, only a $1.35 \%$ reduction in leaching. Again, the scale of the studied process might explain this discrepancy between studies.

\section{Conclusions}

This study clearly indicated that local management can significantly reduce tip burn incidence when compared to a global management approach. The tip burn reduction due to a better homogeneity of the crop into local management has resulted in a marketable biomass increase of $16.5 \%$ to $18.2 \%$ with respect to global management irrigation approach. However, these higher yields and more uniform development has resulted in increasing water consumption by the crop, local management resulting in an augmentation of 18 to $23.6 \%$ of applied water and 21.2 to $100 \%$ in energy consumption, due to higher irrigation frequency. This higher frequency for local irrigation also resulted in more leaching. However, local irrigation management resulted in increasing water use efficiency by a better control in tip burn. This study indicates the relevance for growers to develop a spatial and real time approach for irrigation decision and achieve a better control of this lettuce physiological disorder.

\section{Acknowledgements}

The authors acknowledge the financial contribution of the Natural Science and Engineering Research Council of Canada (NSERC), Le Fonds de Recherche du Québec - Nature et Technologies (FQRNT), as well as Productions horticoles Van Winden Inc., Delfland Inc., Vert Nature Inc., Maraîchers JPL Guerin \& Fils Inc., and Les Fermes Hotte et Van Winden Inc., for their financial and technical support. 


\section{References}

[1] Périard, Y., Irrigation spatio-temporelle de la laitue Romaine en sol organique. Master thesis, Département des sols et de génie agroalimentaire, Université Laval, Québec, Canada. 2012.

[2] Statistique Canada, Utilisation de l'eau à des fins agricoles au Canada, Statistique Canada, 16-402-X, pp. 9-10, 2010.

[3] MAPAQ. 2009. Profil sectoriel de l'industrie horticole au Québec. Edition 2009. Ministère de l'Agriculture, des Pêcheries et de l'Alimentation du Québec. 111 p.

[4] Van Pelt, R.S. and Wierenga, P.J., Temporal stability of spatially measured soil matric potential probability density function, Soil Science Society of America Journal, 65, pp. 668-677, 2001.

[5] Warrick, A.W. and Gardner, W.R., Crop yield as affected by spatial variations of soil and irrigation. Water resources research. 19(1), pp. 181186, 1983.

[6] Letey, J., Vaux, H.J. and Feinerman, E., Optimum crop water application as affected by uniformity of water infiltration. Agronomy Journal. 76, pp. 435-441, 1984.

[7] Nijbroek, R., Hoogenboom, G. and Jones, J.W., Optimizing irrigation management for a spatially variable soybean field. Agricultural Systems. 76(1), pp. 359-377, 2003.

[8] Van Wesenbeeck, I.J., Kachanoski, R.G. and Rolston, D.E., Temporal persistence of spatial patterns of soil water content in the tilled layer under a corn crop, Soil Science Society of America Journal. 52, pp. 934-941, 1988.

[9] Watson, J. Soil Water Variability and Crop Yields. Symposium-Evaluating Water Flux in the Vadose Zone: Computational Methods and Geostatistical Approaches-Solutions to Scaling and Spatial Variability Problems: In Honor of Art Warrick, ed. J. Watson, New Orleans, Louisiana, 2007.

[10] Yeh, T.-C.J., Gelhar, L.W. and Wierenga, P.J., Observations of spatial variability of soil water pressure in a field soil, Soil Science. 142(1), pp. 7 $12,1986$.

[11] Greminger, P.J., Sud, Y.K. and Nielsen, D.R., Spatial variability of fieldmeasured soil-water characteristics. Soil Science Society of America Journal. 49, pp. 1075-1082, 1985.

[12] Hedley, C.B., Yule, I.J., Tuohy, M.P. and Vogeler, I., Key performance indicators for simulated variable-rate irrigation of variable soils in humid regions. American Society of Agricultural and Biological Engineers. 52(5), pp. 1575-1584, 2009a.

[13] Lafond, J., J. Caron, Y. Périard and S. Jutras. Spatial variability analysis of soil water availability for plants as a tool for precision irrigation in organic soils. ASA-CSSA-SSSA International Annual Meetings, eds. M. Young and T. R, Green San Antonio, TX, USA, 2011.

[14] Hodnett, M.G., Bell, J.P., Ah Koon, P.D., Soopramanien, G.C. and Batchelor, C.H., The control of drip irrigation of sugarcane using "index" 
tensiometers: some comparisons with control by the water budget method. Agricultural Water Management. 17, 189-207, 1990.

[15] Hendrickx, J.M.H. and Wierenga, P.J., 1990. Variability of soil water tension in a trickle irrigated Chile pepper field. Irrigation Science. 11, pp. 23-30.

[16] King, B.A. and Kincaid, D.C., A variable flow rate sprinkler for site-specific irrigation management. Applied Engineering in Agriculture. 20(6), pp. 765-770, 2004.

[17] Dukes, M.D. and Perry, C., Uniformity testing of variable-rate center pivot irrigation control systems. Precision Agriculture. 7(3), pp. 205-218, 2006.

[18] Chávez, J.L., Pierce, F.J. and Evans, R.G., Compensating inherent linear move water application errors using a variable rate irrigation system. Irrigation Science. 28(3), pp. 203-210, 2010.

[19] Feinerman, E. and Voet, H., Site-specific management of agricultural inputs: an illustration for variable-rate irrigation. European Review of Agricultural Economics. 27(1), pp. 17-37, 2000.

[20] Lu, Y.C., Sadler, E.J. and Camp, C.R., Economic feasibility study of variable irrigation of corn production in southeast coastal plain. Journal of Sustainable Agriculture. 26, pp. 69-81, 2005.

[21] DeJonge, K.C., Kaleita, A. L. and Thorp, K.R., Simulating the effects of spatially variable irrigation on corn yields, costs, and revenue in Iowa. Agricultural Water Management. 92, pp. 99-109, 2007.

[22] El Nahry, A.H., Ali, R.R. and El Baroudy, A.A., An approach for precision farming under pivot irrigation system using remote sensing and GIS techniques. Agricultural Water Management. 98(4), pp. 517-531, 2011.

[23] Sadler, E.J., Evans, R.G., Stone, K.C. and Camp, C.R., Opportunities for conservation with precision irrigation. Journal of Soil and Water Conservation. 60(6), pp. 371-379, 2005.

[24] Oliveira, C., Yoder, R.E. and Larson, J., Evaluating the returns to sitespecific irrigation. Proc. of the 7th International Conference on Precision Agriculture and Other Precision Resources Management, ed. D.J. Mulla, Minneapolis, pp. 756-770, 2004.

[25] King, B.A., Stark, J.C. and Wall, R.W., Comparison of site-specific and conventional uniform irrigation management for potatoes. American Society of Agricultural and Biological Engineers. 22(5), 677-688, 2006.

[26] Al-Kufaishi, S.A., Blackmore, B.S. and Sourell, H., The feasibility of using variable rate water application under a central pivot irrigation system. Irrigation and Drainage Systems. 20, pp. 317-327, 2006.

[27] Jobbágy, J., Simoník, J. and Findura, P., Evaluation of efficiency of precision irrigation for potatoes. Res. Agr. Eng. 57 (Special Issue): S14S23, 2011.

[28] Soil Classification Working Group. The Canadian system of soil classification, 3rd ed. General Direction of Research, Agriculture and AgriFood Canada, publication 1646. National Research Council Canada, Ottawa (ON). 1998. 
[29] Plamondon-Duchesneau, L., Gestion de l'irrigation des laitues romaines (Lactuca Sativa L.) cultivées en sol organique. Master thesis, Département de phytologie, Université Laval, Québec, Canada. 2011.

[30] Bergeron-Piette, E., Pertes d'eau et de solutés durant l'irrigation des laitues romaines en sols organiques : comparaison de méthodes d'évaluation et impacts sur les rendements. Master thesis, Département des sols et de génie agroalimentaire, Université Laval, Québec, Canada, 2011.

[31] Aggelides, S., Assimakopoulos, I. Kerkides, P. and Skondras, A., Effects of soil water potential on the nitrate content and the yield of lettuce. Communications in Soil Science and Plant Analysis, 30(1\&2), 235-243, 1999.

[32] van Genuchten, M.Th., A closed-form equation for predicting the hydraulic conductivity of unsaturated soils. Soil Science Society of America Journal. 44, pp. 892-898, 1980.

[33] Baird, A.J. and Gaffney, S.W., Solute movement in a drained fen peat: a tracer study in a Somerset (UK) wetland. Hydrological Processes. 14, pp. 2489-2503, 2000.

[34] Boudreau, J., Caron, J., Elrick, D., Fortin, J. and Gallichand, J., Solute transport in sub-irrigated peat-based growing media. Canadian Journal of Soil Science, 89, pp. 301-313, 2009.

[35] Janzen, H.H, Soluble Salts (Chapter 18). Soil sampling and methods of analysis, ed. M.R. Carter, CRC Press LLC. Boca Raton, Florida, USA, pp. 161-166.1993.

[36] R Development Core Team (2012). R: A language and environment for statistical computing. R Foundation for Statistical Computing, Vienna, Austria, Online. http://www.r-project.org/

[37] Pinheiro, J., Bates, D., DebRoy, S., Sarkar, D. and the R Development Core Team, nlme: Linear and Nonlinear Mixed Effects Models. R package version 3.1-103. 2012.

[38] Bates, D., Maechler, M. and Bolker, B., lme4: Linear mixed-effects models using S4 classes. R package version 0.999375-42. 2011.

[39] Hedley, C.B. and Yule, I.J., Soil water status mapping and two variable-rate irrigation Scenarios. Precision Agriculture. 10, 342-355, $2009 \mathrm{~b}$. 